\title{
Household wealth inequality, entrepreneurs' financial constraints, and the great recession: evidence from the Kauffman Firm Survey
}

\author{
Fabio Braggion • Mintra Dwarkasing • Steven Ongena
}

\begin{abstract}
We empirically test if household wealth inequality affects borrowing constraints of young entrepreneurs. We construct a measure of wealth inequality at the US county level based on the distribution of financial rents in 2004. We find that in more unequal areas, entrepreneurs are less likely to apply for a loan fearing that their applications will be turned down and they use more of their own funds to finance their ventures. In more unequal areas, the number of bank establishments per capita is lower, this effect being stronger during the 2007-2008 financial crisis.
\end{abstract}

F. Braggion $(\bowtie)$

CentER - Tilburg University, Tilburg, The Netherlands

e-mail: f.braggion@uvt.nl

F. Braggion

Department of Finance, PO Box 90153, 5000 LE Tilburg,

The Netherlands

M. Dwarkasing

Erasmus University Rotterdam, Rotterdam, The Netherlands

e-mail: dwarkasing@ese.eur.nl

M. Dwarkasing

Department of Business Economics, Erasmus School of

Economics, Business Economics, Burgemeester Oudlaan 50, PO

Box 1738, 3000 DR Rotterdam, The Netherlands

S. Ongena

University of Zürich, SFI and CEPR, Zürich, Switzerland

e-mail: steven.ongena@bf.uzh.ch

S. Ongena

Department of Banking and Finance, University of Zürich, Plattenstrasse 32, CH-8032 Zürich, Switzerland
Keywords Wealth inequality - Entrepreneurship . Financial constraints

JEL classification $\mathrm{D} 31 \cdot \mathrm{G} 3 \cdot \mathrm{L} 26$

\section{Introduction}

Entrepreneurs are central in the process of economic growth. Entrepreneurial activities spur capital formation, generate technological progress, and create employment. To perform their tasks, entrepreneurs need financial resources that they usually do not have when they intend to start their business. In theory, capital markets should provide the means to finance profitable business projects. However, an important area of research has shown that in many occasions, entrepreneurs face financial constraints, that is, financiers are unwilling or unable to provide funding to positive net present value projects (see Kerr and Nanda (2009) for a review). Various studies have identified poor legislation, adverse local or national culture, and weak institutions amongst the possible causes of entrepreneurs' inability to raise finance.

In this paper, we examine the role of another possible determinant of entrepreneurial financial constraints: wealth inequality. In many instances, wealth inequality has been linked to bad economic outcomes. Engerman and Sokoloff (2002), for example, describe how wealthy elites may prevent the development of important institutions that foster economic growth to keep their hold on power: Capital markets are one of these important 
institutions. Anecdotal evidence suggests that in countries with a large inequality in wealth, for example Latin America, banks mostly serve the needs of few industrial groups owned by wealthy families. They are less concerned of providing funds to the middle class in the form of, amongst others, supporting young entrepreneurs and small/medium enterprises (see Hoffman et al. (2007), p. 92).

Following Braggion et al. (2016), our study will link the degree of wealth inequality in US counties to various measures of entrepreneurs' financial constraints. We will also see whether inequality affected differently entrepreneurs' financial constraints before and after the 2007-2008 financial crisis. The USA is a country where capital markets have been considered most efficient and where access to finance should be the easiest (Rajan and Zingales 1998). Any result we may find here could be considered a lower bound of what we would find in any other environment.

We base our analysis on the Kauffman Firm Survey. Amongst various data items, the survey explicitly asks entrepreneurs whether they expect troubles in raising finance. In particular, the Survey reports whether entrepreneurs do not apply for a loan to a financial institution, even if they need financing, fearing that their application will be turned down. We will investigate whether entrepreneurs located in more unequal areas are more likely to renounce to a loan application. We also corroborate our findings by looking at the proportion of owners' equity (i.e. entrepreneurs' own resources) to firm total financing. Everything else equal, we should expect that tighter financial constraints should induce entrepreneurs to use a larger proportion of their own funds to finance the venture.

In the second part of our study, we will relate wealth inequality to a proxy of local supply of bank finance. Like in Braggion et al. (2016), we measure local supply of bank finance with the number of bank establishments formation. Differently from Braggion et al. (2016), we will also analyze the relationship between inequality and the number of bank establishments per capita during the 2007-2008 financial crisis.

The empirical methodology in this paper is based on Braggion et al. (2016). As in that paper, we proxy wealth inequality with a measure that relies on the amounts of dividends and interests earned by US households in 2004 (the first year for which these data are available) as reported by Internal Revenue Service (IRS) Statistics of Income (IRS-SOI) data. The IRS-SOI data report the total amount of dividends and interest income received by US households in each postal zip code. Under the assumption that a typical household holds the market index for stocks and bonds, the amount of financial rents it receives depends only on the quantity of stocks and bonds it holds - in other words, by the total amount of financial wealth it owns.

Naturally, local wealth inequality could be correlated with factors that may directly affect the probability of entrepreneurs to access external finance. We address this issue in two ways. First, by using county level data, we can control for State level unobserved variables that could be correlated with the local level of inequality. Second, we rely on the historical literature and instrument our measure of local wealth inequality with variables related to the local weather pattern. As indicated by Engerman and Sokoloff (2002), local weather conditions may generate different patterns of inequality by sustaining different types of crops that display different fixed costs.

In our analysis, we find that, when we instrument the wealth inequality measure, in more unequal areas, entrepreneurs are less likely to apply for a loan as they fear to be turned down. This effect is both statistically and economically significant, a standard deviation increase in local wealth inequality increases this probability by $73 \%$. Similarly, in more unequal counties, entrepreneurs rely more on their equity to set up their business. The effect is also economically meaningful. A standard deviation increase in wealth inequality increases the proportion of owners' equity to total finance with $33 \%$, evaluated at the mean of the dependent variable. We find that these effects are concentrated in the pre-2008 period, after the financial crisis inequality does not have a statistically significant effect on entrepreneurs' access to finance. We interpret these results as evidence that banks cut credit across the board without distinguishing amongst entrepreneurs located in different areas. Looking at the aggregate figures, however, we find that in more unequal counties, the number of banking establishment per capita becomes lower after 2008, suggesting that, following the crisis, banks retreated from areas where wealth inequality is higher. The relationship between bank establishments per capita and local wealth inequality is between 2 and $10 \%$ stronger during the 2007-2008 financial crisis. While the first part of our analysis shows that during the crisis, banks cut credit equally to every entrepreneur, and the second part suggests that banks were more likely to fail and divest in 
areas with higher wealth inequality. The first part of the analysis lends support to the notion that the crisis corresponded to a generalized credit crunch to entrepreneurial activities. In the second part, we show some novel evidence that the investment in "banking infrastructure" declined more in unequal counties. The latter effect suggests that the crisis may have longer lasting effects in unequal areas.

Overall, these results support the notion that wealth inequality is a relevant factor in explaining financial constraints of entrepreneurs. Our paper contributes to the large literature that identifies the determinants of financial constraints on firms and startups. Starting from King and Levine (1993) and Levine and Zervos (1998), we know that size and the depth of financial markets are positively related to economic growth. Another set of analyses have linked the development of capital markets to entrepreneurship. Black and Strahan (2002), Cetorelli and Strahan (2006), and Kerr and Nanda (2009), for instance, find large increases in startup activity subsequent to the US inter-state branch banking deregulation. Fisman and Love (2004) show that startup firms struggle with overcoming weaknesses in financial market development. Comin and Nanda (2014) show that difficulties faced by startups in raising capital might negatively affect the commercialization of new technologies.

This paper proceeds as follows. Section 2 discusses the theoretical frameworks, the relationships between wealth inequality and finance and our empirical strategy. Section 3 describes the data sources. Section 4 presents our results and Section 5 concludes.

\section{Background and empirical methods}

As in Braggion et al. (2016), our hypotheses are based on the work of Engerman and Sokoloff (1997), Engerman and Sokoloff (2002), Glaeser et al. (2003), and Sonin (2003). These papers describe how the emergence of wealthy elites may prevent the development of institutions designed to preserve their political power and to maintain the existing level of inequality. As a result, unequal societies will be characterized by, amongst other things, a less effective educational system, a poor judiciary and-especially important for us-less efficient capital markets.

Anecdotal and historical evidence, as well as formal econometric works, support the notion that higher wealth inequality may prevent a sound development of a financial system. In especially unequal countries, banks appear to be designed to serve the interests of large industrial groups owned by wealthy families (Hoffman et al. 2007, p. 92). In Porfirian Mexico, for instance, the banking sector was designed to have the powerful elites to support the dictatorship. Wealthy families became shareholders of the largest banks in the country. Large returns to their investment were assured by granting monopoly powers, legal privileges, and a set of tax exemptions to the same banks (Calomiris and Haber 2014, pp. 340-347). In Brazil, banks historically have been a tool to extract inflation tax from the poor and the middle class as the State did not have neither the willingness nor the power to impose to the wealthy the payment of an income tax (Calomiris and Haber 2014, pp. 399-402). These historical accounts are also corroborated by econometric evidence. For instance, Morck et al. (2011) observe a less efficient allocation of capital in countries whose banking systems are controlled by wealthy families. Moreover, family control of banks also appears to be related with slower economic growth and greater financial instability. Rajan and Ramcharan (2011), using data from the 1930s, show that US counties with more land inequality had less banks establishment per capita. They interpret this as evidence of an underdevelopment of the financial markets and undersupply of credit. Amongst other things, Braggion et al. (2016) find similar results using contemporary US data and a measure of local wealth inequality based on the distribution of financial rents.

Engerman and Sokoloff also describe the factors that can be underlying persistent differences in inequality: different climates and geographical environments that may favor one type of crop over another. Their argument suggests that climates that are best suited for large plantations, like sugar or tobacco, will induce relatively high economic inequality. The production of these crops comes at a high fixed cost; as a result, the market, in equilibrium, can support only a few farms. The outcome is thus a society controlled by few wealthy landowners. Climates suitable for crops like tobacco and cotton are characterized by higher and steadier temperatures and more rainfalls per year. Conversely, climates supporting crops like wheat will result in a more equal society. The production of these crops does not require high fixed costs; hence, the market can "bear" more producers. These societies will be more equal and mainly composed of small landowners. Climates supporting these 
crops have lower and more variable temperatures, as well as less (and more variable) rainfalls during the year. An additional feature of this theoretical framework is that inequality and "bad" institutions will be persistent over time and reinforce each other. Along these lines, Rajan (2009) provides a theoretical framework and empirical evidence of how institutions may persist throughout time.

We will combine these insights in our empirical analysis and instrument our measure of wealth inequality with the secular pattern of rainfall and temperature in various US areas. In our first-stage regressions, we expect that areas with higher temperature and more rainfalls will display higher wealth inequality. Similarly, areas with steadier temperature and steadier rainfalls should also have higher wealth inequality.

Various works have shown that this sets of instruments are unlikely to violate the exclusion restrictions, that is, they are more likely to proxy factors related to the quality of the local institutional environment, amongst them the supply of finance. Rajan and Ramcharan (2011), for instance, provide evidence suggesting that the type of weather in US counties is unrelated with entrepreneurs' demand of finance.

Importantly for our analysis, the type of weather can vary quite significantly within states and across different counties. In Kansas and Texas, for instance, some counties experience a yearly rainfall average of 20 in, while others exceed $40 \mathrm{in}$. A bit less extreme but still important are the differences in Illinois, where some counties have an average rainfall of 28 in, while others have $30 \%$ more (approximately 36 in.). Similarly, in California, some counties had an average temperature of $50 \mathrm{~F}$, while others have an average of $64 \mathrm{~F}$. Rajan and Ramcharan (2011) and Vollrath (2013) provide similar evidence (see also Braggion et al. 2016).

In our main analysis, we will estimate the relationship between wealth inequality and measures of financial constraints. In particular, we will estimate the following equation:

$$
\begin{aligned}
Y_{i, j, t}= & \alpha+\alpha_{s}+\alpha_{\text {Ind }}+\alpha_{t}+\beta \text { Wealth Inequality }_{j} \\
& + \text { Controls }_{j, t-1}+\varepsilon_{i, t}
\end{aligned}
$$

where $Y_{i, j, t}$ indicates different financial constraints variables of startup $i$ located in county $j$ at year $t$. As we have firm-level data, we additionally control for industry fixed effects together with the state and year fixed effects. Controls capture two sets of county and firm characteristics. In many specifications, we will instrument local wealth inequality with the local secular pattern of rainfall and temperature.

In the second part of the analysis, we will check the relationship between local inequality and local supply of finance measured by the number of bank establishments per capita.

We will especially analyze whether the impact of inequality on the local supply of finance is stronger after the 2007-2008 financial crisis. The financial crisis led banks to freeze their lending and possibly generate a tightening of financial constraints to entrepreneurs:

$$
\begin{aligned}
Y_{j, t}= & \alpha+\alpha_{s}+\alpha_{t}+\beta \text { Wealth Inequality }_{j} \\
& +\gamma \text { SubPrime Crisis } * \text { Wealth Inequality }_{j} \\
& + \text { Controls }_{j, t-1}+\varepsilon_{j, t}
\end{aligned}
$$

Post is a dummy variable that takes the value of 1 for the years following 2007 and 0 otherwise. The interaction term SubPrime Crisis*Wealth Inequality captures the differential effect of wealth inequality in the aftermath of the financial crisis.

\section{Data}

\subsection{Data sources}

Our main data source is the Kauffman Firm Survey (KFS) panel dataset. From the KFS, we extract the financial information for an 8-year period from 2004 up to (and including) 2011 on individual US start-ups during their early years of operation (see Robb and Robinson 2014 for a comprehensive discussion of the capital structure choices of firms covered by this survey). This information is particularly useful to reconstruct the sources of financing of these young firms and allows us to identify amongst others the amounts of equity owners put in the firm themselves. The survey also asks questions to the young entrepreneurs. In particular, to get an idea of the extent of possible problems to obtain financial resources, we consider the binary question (yes = 1, 0 otherwise): "Was there any time when the business needed credit but did not apply because you or others associated with the business thought the application would be denied?" We label this question "Financial Constraint," where a positive 
answer may indicate a firm to be more financially constraint. ${ }^{1}$

We collect the data on the amount of equity invested by the owners for our additional firm's financing regressions from the same database. The dataset contains response-adjusted weights (which we use) to minimize the potential non-response bias in the estimates. From this database, we construct our measure of the amount of owners' equity to total financing, as well as control variables in the form of firm and main owner characteristics. We download the various state, MSA, and county characteristics from the US Census Bureau. We obtain data on banking establishments per capita also from the US Census Bureau. This information is available from 2004 to 2009.

The contemporary measure of wealth inequality looks at the amounts of dividends and interest earned by US households in 2004, the first year in our sample period, as reported by the Internal Revenue Service (IRS) Statistics of Income (SOI) data. The IRS-SOI data report the total amount of dividends and interest income received by US households in a certain zip code. The information is reported as a total amount per zip code and is divided into five households' income groups, ranging from low income to high income. Under the assumption that a typical household owns the market index for stocks and bonds, the amount of financial rents it receives depends only on the quantity of stocks and bonds it holds. We use this information to construct a Gini index of wealth inequality based on financial rents. Details on its construction are provided in Braggion et al. (2016). ${ }^{2}$

Our instrumental variables are based on local weather patterns. We obtain information from the National Climatic Data Center (NCDC) on local monthly precipitation and temperature (measured in inches and degrees Fahrenheit, respectively) and their corresponding standard deviations for the entire period between 1895 and 2003. We then construct simple averages of these series. The NCDC provides this weather information at the socalled "divisional" level, i.e., each state is subdivided into at most 10 divisions that comprised areas that are known to have similar climatic conditions. We assign each county to the state division to which it belongs. The definitions of our variables are provided in Table 1 ,

\footnotetext{
${ }^{1}$ Given that this question is only asked from 2007 onwards, we can only analyze it for these years.

${ }^{2}$ See the internet appendix at the end of the paper.
}

whereas the descriptive statistics are presented in Table 2. Tables 1 and 2 directly provide the list of control variables we use both at the county and the individual/entrepreneur level.

\section{Results}

\subsection{Financial constraints}

In this section, we present results showing a relationship between US counties wealth inequality and financial constraints.

In the first set of results, we measure financial constraints by directly looking at the probability that an entrepreneur renounces to apply for a loan, even if she needs financing, fearing that she will be turned down. Table 3 Panel (A), Columns (2)-(6) consider this possibility and we first study the pre-crisis period. Column (1) shows the results of the first-stage regression for the IV regressions performed in Table 3. As expected, the average amount of rainfall and the average temperature are positively related with wealth inequality. The standard deviation of rain is negatively related with wealth inequality that is areas with steadier and more predictable rainfalls tend to be more unequal. The standard deviation of temperature enters with a negative sign but not statistically significant at conventional levels. Column 2 shows the results of the OLS regression where the dependent variable is financial constraints as previously defined. The coefficient on wealth inequality is negative and not statistically significant. To move away from the mere correlations between inequality and financial constraints that the OLS results provide to causation, we use an instrumental variable approach. Columns (3)-(5) present the results of the two-stage least squares second-stage regressions where wealth inequality is instrumented with the secular means and standard deviations of temperature and rainfall. The coefficient is positive and statistically significant, indicating that in more unequal counties, entrepreneurs are more likely to renounce to a loan application. In other words, in more unequal areas, entrepreneurs are more likely to refrain from applying for bank financing, even though needed, as they expect that a possible loan application will be denied. The effect is also economically sizable: A standard deviation increase in local wealth inequality increases such probability with around 
Table 1 Variable names, definitions, and data sources for the empirical analysis of firm ownership, financing, and type

\begin{tabular}{|c|c|c|}
\hline Variable name & Variable definition & Source \\
\hline \multicolumn{3}{|l|}{ Dependent variables } \\
\hline $\begin{array}{l}\text { Bank establishments per } \\
\text { capita }\end{array}$ & The total number of bank establishments per capita in a given county & USC \\
\hline Firm equity & The amount of equity invested by the main owners of the business & $N S F$ \\
\hline Financial constraint & $\begin{array}{l}=1 \text { if a firm answers "yes" to the question: "Was there any time when the business needed credit but } \\
\text { did not apply because you or others associated with the business thought the application would be } \\
\text { denied?", =0 otherwise. }\end{array}$ & $K F S$ \\
\hline \multicolumn{3}{|c|}{ Main independent variables } \\
\hline $\begin{array}{l}\text { County inequality in } \\
2004\end{array}$ & $\begin{array}{l}\text { The Gini coefficient of the distribution of wealth as measured by the distribution of the amount of } \\
\text { declared dividends from household tax filings in the county }\end{array}$ & IRS \\
\hline MSA inequality in 2004 & $\begin{array}{l}\text { The Gini coefficient of the distribution of wealth as measured by the distribution of the amount of } \\
\text { declared dividends from household tax filings in the metropolitan statistical area (MSA) }\end{array}$ & $\operatorname{IRS}$ \\
\hline \multicolumn{3}{|l|}{ Instrumental variables } \\
\hline Rain & $\begin{array}{l}\text { The average district precipitation between } 1895 \text { and 2003, where a district is defined as a group of } \\
\text { clustered counties with similar climatic conditions }\end{array}$ & $N C D C$ \\
\hline Temperature & $\begin{array}{l}\text { The average district temperature in degrees between } 1895 \text { and 2003, where a district is defined as a } \\
\text { group of clustered counties with similar climatic conditions }\end{array}$ & $N C D C$ \\
\hline \multicolumn{3}{|c|}{ 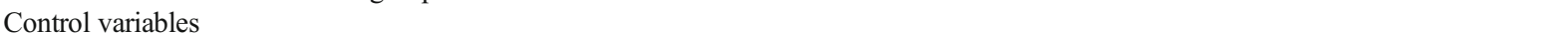 } \\
\hline \multicolumn{3}{|l|}{ Firm characteristics } \\
\hline Firm total assets $_{t-1}$ & $\begin{array}{l}\text { The logarithm of one plus total assets, which is the sum of cash, accounts receivable, product inventory, } \\
\text { equipment or machinery, land and buildings, vehicles, other business owned property and other assets }\end{array}$ & $K F S$ \\
\hline Firm $\mathrm{ROA}_{t-1}$ & Return on Assets, i.e., the amount of net profit divided by total assets winsorized at the $1 \%$ level & $K F S$ \\
\hline Firm tangibility $t_{t-1}$ & The amount of property, plant, and equipment divided by total assets & KFS \\
\hline $\begin{array}{l}\text { Application } \\
\text { experience }\end{array}$ & $\begin{array}{l}=0 \text { if the firm did not apply for credit in a given year, }=1 \text { if the firm's credit applications were always } \\
\text { approved, =2 if they were sometimes approved and sometimes denied, }=3 \text { if they were always denied }\end{array}$ & KFS \\
\hline $\begin{array}{l}\text { Firm number of } \\
\text { owners }_{t-1}\end{array}$ & The logarithm of one plus the total number of owners & $K F S$ \\
\hline \multicolumn{3}{|l|}{ Main owner characteristics } \\
\hline Main owner is female & $=1$ if main owner is a female, $=0$ otherwise & KFS \\
\hline $\begin{array}{l}\text { Main owner is } \\
\text { African-American }\end{array}$ & $=1$ if main owner is African-American, $=0$ otherwise & KFS \\
\hline $\begin{array}{l}\text { Main owner is } \\
\text { Hispanic }\end{array}$ & $=1$ if main owner is Hispanic, $=0$ otherwise & $K F S$ \\
\hline Main owner is Asian & $=1$ if main owner is Asian, $=0$ otherwise & KFS \\
\hline $\begin{array}{l}\text { Main owner is born in } \\
\text { the USA }\end{array}$ & $=1$ if main owner was born in the USA, $=0$ otherwise & KFS \\
\hline $\begin{array}{l}\text { Main owner's work } \\
\text { experience }\end{array}$ & Number of years of work experience of the main owner in the firm's industry & $K F S$ \\
\hline \multicolumn{3}{|l|}{ County characteristics } \\
\hline County population & Total county population at year-end & USC \\
\hline State GDP per capita & State GDP dividend by State Population & USC \\
\hline $\begin{array}{l}\text { County wage } \\
\text { inequality }\end{array}$ & $\begin{array}{l}\text { The Gini coefficient of the distribution of wages as measured by the distribution of the amount of } \\
\text { labor from household tax filings in the county }\end{array}$ & IRS \\
\hline County land area & The logarithm of one plus the total county area in square miles at year-end 2000 & USC \\
\hline
\end{tabular}

The table defines the variables used in the empirical analysis of firm ownership, financing and type, and the corresponding data sources used. Total firm financing is the sum of total debt and equity financing. $t-1$ indicates that a 1 -year lag is used in the empirical analysis. For the sake of brevity, we do not report the MSA characteristics separately

BEA Bureau of Economic Analysis, IRS Internal Revenue Service, KFS Kauffman Firm Survey, NCDC National Climatic Data Center, NSF National Science Foundation, USC US Census 
Table 2 Descriptive statistics

\begin{tabular}{|c|c|c|c|c|c|c|c|}
\hline Variable name & $\begin{array}{l}\text { Number of } \\
\text { observations }\end{array}$ & Units & Mean & $\begin{array}{l}\text { Standard } \\
\text { deviation }\end{array}$ & $10 \%$ & $\begin{array}{l}\text { Median } \\
(50 \%)\end{array}$ & $90 \%$ \\
\hline \multicolumn{8}{|l|}{ Dependent variables } \\
\hline Firm equity & 17,542 & - & 0.33 & 0.40 & 0.00 & 0.08 & 1.00 \\
\hline Financial constraint & 12,096 & $0 / 1$ & 0.17 & 0.38 & 0.00 & 0.00 & 1.00 \\
\hline Bank establishments per capita & 18,834 & & 0.49 & 0.32 & 0.23 & 0.40 & 0.85 \\
\hline \multicolumn{8}{|l|}{ Main independent variable } \\
\hline County inequality in 2004 & 35,757 & - & 0.85 & 0.05 & 0.79 & 0.85 & 0.90 \\
\hline \multicolumn{8}{|l|}{ Instrumental variables } \\
\hline Rain & 22,208 & Inch & 3.05 & 1.08 & 1.35 & 3.17 & 4.36 \\
\hline Temperature & 20,497 & ${ }^{\circ} \mathrm{F}$ & 54.89 & 8.41 & 45.12 & 53.02 & 68.71 \\
\hline \multicolumn{8}{|l|}{ Control variables } \\
\hline \multicolumn{8}{|l|}{ Firm characteristics } \\
\hline $\begin{array}{l}\text { Firm total assets } \\
\text { (natural logarithm) }\end{array}$ & 24,319 & (USD) & 9.48 & 3.82 & 0.00 & 10.31 & 13.11 \\
\hline Firm ROA & 20,762 & - & 0.27 & 2.29 & -0.83 & 0.05 & 1.67 \\
\hline Firm tangibility & 21,769 & - & 0.56 & 0.37 & 0.00 & 0.64 & 1.00 \\
\hline Application experience $_{t}$ & 12,094 & - & 0.18 & 0.55 & 0 & 0 & 1 \\
\hline $\begin{array}{l}\text { Firm number of owners } \\
\text { (natural logarithm) }\end{array}$ & 24,660 & - & 0.92 & 0.42 & 0.69 & 0.69 & 1.39 \\
\hline \multicolumn{8}{|l|}{ Main owner characteristics } \\
\hline Main owner is female & 24,346 & $0 / 1$ & 0.26 & 0.44 & 0 & 0 & 1 \\
\hline $\begin{array}{l}\text { Main owner is African- } \\
\text { American }\end{array}$ & 24,553 & $0 / 1$ & 0.07 & 0.26 & 0 & 0 & 0 \\
\hline Main owner is Hispanic & 24,553 & $0 / 1$ & 0.05 & 0.21 & 0 & 0 & 0 \\
\hline Main owner is Asian & 24,553 & $0 / 1$ & 0.04 & 0.21 & 0 & 0 & 0 \\
\hline Main owner is born in the USA & 24,332 & $0 / 1$ & 0.90 & 0.31 & 0 & 1 & 1 \\
\hline Main owner's work experience & 24,336 & - & 13.51 & 10.82 & 1 & 11 & 30 \\
\hline \multicolumn{8}{|l|}{ State/county characteristics } \\
\hline $\begin{array}{l}\text { County population } \\
\text { (natural logarithm) }\end{array}$ & 32,300 & - & 13.15 & 1.54 & 10.98 & 13.35 & 15.47 \\
\hline $\begin{array}{l}\text { County personal income per } \\
\text { capita }\end{array}$ & 19,432 & (USD) & 28,315 & 7562 & 21,541 & 26,386 & 36,260 \\
\hline County wage inequality & 35,757 & - & 0.54 & 0.03 & 0.50 & 0.54 & 0.58 \\
\hline $\begin{array}{l}\text { County land area } \\
\text { (natural logarithm) }\end{array}$ & 24,065 & sq mi & 14.41 & 0.66 & 13.78 & 14.46 & 15.06 \\
\hline
\end{tabular}

The table provides the number of observations, mean, standard deviation, 10th percentile, the median (50th percentile), and the 90th percentile of all variables used in the empirical analysis. The definition of the variables is found in Table 1 . Due to confidentiality, the minimum and maximum are not reported

12.72 percentage points, $73 \%$ in respect to its mean. In Column 6, we consider the time period 2007-2011, the entire time frame for which information is available on financial constraints. The coefficient on Wealth Inequality is still positive, but no longer statistically significant: The introduction of the crisis period weakens the relationship between inequality and access to finance. We interpret this result as evidence that during the crises, banks may have cut credit to all entrepreneurs independently of their location. If financial constraints are an issue for entrepreneurs, we should see that holding everything else constant, in more unequal counties, startups are especially financed with entrepreneurs' own resources. We explore this issue in Table 3 Panel (B) and start with examining the 2004-2008 period. Panel B, Column (1) presents the first-stage regression. 
Like in Panel (A), average rainfall, average temperature, and standard deviation of rain have the expected sign, and they are statistically significant. In Column 2, we consider the OLS where the coefficient on wealth inequality is negative and not statistically significant. Again to move away from correlations to causation, we perform instrumental variable analyses. Columns (3)-(5) look at the two-stage least square regressions during the period 2004-2008. In Column (3), where we do control for State and Year fixed effects, but not for county and firms controls, the coefficient on inequality loads negatively but is not statistically significant at conventional levels. However, when including a broad set of firm and county controls as well as various fixed effects (both state and industry trends, i.e., state * year and industry * year fixed effects) in both Columns (4) and (5), the coefficient on wealth inequality enters positively and it is statistically significant. Again, the economic significance is important. A one standard deviation increase in wealth inequality leads to an increase of entrepreneur's equity of around 9.96 percentage points, which is $30 \%$ with respect to the mean of the dependent variable. In Column (6), we consider the full sample: The coefficient on Wealth inequality is still positive and marginally statistically significant. The size of the coefficient is, however, very similar to the coefficients we obtain in the 2004-2008 period.

An interesting outcome of our analysis is that the OLS estimates always provide a negative relationship between wealth inequality and our proxies of financial constraints. Even more importantly, the coefficients relating wealth inequality to financial constraints and owners' equity are very small in absolute value with economic significance close to zero. It appears that endogeneity biases the coefficients against finding any result. A possible interpretation is that in more unequal areas, only very creditworthy individuals become entrepreneurs. These individuals are more likely to obtain bank finance, they do not fear to have a loan application turned down, and they rely less on their own equity to finance their ventures. As a result, the negative impact of inequality on the possibility to obtain external finance is offset by the good creditworthiness of entrepreneurs in unequal counties. It appears that our instruments capture the elements of the local institutional environment that prevent entrepreneurs from accessing bank finance allowing us to disentangle the negative relationship between inequality and entrepreneurs' access to external finance.

\subsection{Bank establishments per capita}

In an additional analysis, we also check whether in the aggregate, more wealth inequality leads to a lower supply of finance. Like in Braggion et al. (2016), we focus especially on bank finance and we proxy its local supply with the number of bank establishments per capita by county. Differently from Braggion et al. (2016), we explicitly study differential effects of inequality on bank finance supply before and after the 2008 financial crisis.

We present these results in Table 4. Table 4 Columns (1)-(3) present the OLS regressions, whereas Columns (4)-(6) display the 2SLS regressions. ${ }^{3}$ In all specifications, wealth inequality alone has a negative and statistically significant coefficient suggesting that bank establishment per capita is lower in more unequal counties. The effects are economically important: A standard deviation increase in inequality leads to a reduction that ranges between 10 and $30 \%$ of the bank establishments per capita. We also find a negative coefficient on the interaction term between wealth inequality and the financial crisis: The effect of inequality on the supply of bank capital becomes between 2 and 10\% stronger after the financial crisis. This result suggests that banks retreated more in counties that displayed higher levels of wealth inequality: This could have happened either because of banks failures or because banks divested in those areas and closed branches. All in all, our results lend support to the notion that while banks cut credit to all entrepreneurs, they reduced the amount invested in their own infrastructure as a result of the crisis, especially in more unequal counties. This may imply that the financial crisis may have a longer lasting impact in unequal counties.

\section{Conclusions}

In this paper, we explored the role of wealth inequality in explaining financial constraints to entrepreneurs. A set of studies have indicated wealth inequality as a possible determinant of inefficient financial markets, as the wealth elites may distort the development of capital markets to their own benefits. We focus our studies on US counties and MSA areas, and as in Braggion et al. (2016), we constructed local measures

\footnotetext{
${ }^{3}$ We do not report the first stages results in this case, but they look similar to those reported in Table 3.
} 
Table 3 The effect of county inequality on financial constraints and firm equity

\begin{tabular}{|c|c|c|c|c|c|c|}
\hline $\begin{array}{l}\text { Model } \\
\text { Dependent variable }\end{array}$ & $\begin{array}{l}(1) \\
\text { First stage }\end{array}$ & \multicolumn{5}{|c|}{ Financial constraints } \\
\hline \multicolumn{7}{|l|}{ Panel A: financial constraints } \\
\hline County inequality in 2004 & $\begin{array}{l}- \\
-\end{array}$ & $\begin{array}{l}-0.0489 \\
(0.216)\end{array}$ & $\begin{array}{l}1.820 * \\
(1.003)\end{array}$ & $\begin{array}{l}3.659 * \\
(2.113)\end{array}$ & $\begin{array}{l}3.665^{*} \\
(2.119)\end{array}$ & $\begin{array}{l}1.367 \\
(1.864)\end{array}$ \\
\hline County Population ${ }_{t-1}$ & $\begin{array}{l}-0.0033 \\
(0.001)\end{array}$ & $\begin{array}{l}0.0124 \\
(0.008)\end{array}$ & $\begin{array}{l}0.0194 * * * \\
(0.006)\end{array}$ & $\begin{array}{l}0.0203 \\
(0.012)\end{array}$ & $\begin{array}{l}0.0204 \\
(0.012)\end{array}$ & $\begin{array}{l}0.0180 * \\
(0.010)\end{array}$ \\
\hline Rain & $\begin{array}{l}0.0142 * * \\
(0.006)\end{array}$ & $\begin{array}{l}- \\
-\end{array}$ & $\begin{array}{l}- \\
-\end{array}$ & $\begin{array}{l}- \\
-\end{array}$ & $\begin{array}{l}- \\
-\end{array}$ & $\begin{array}{l}- \\
-\end{array}$ \\
\hline Rain standard deviation & $\begin{array}{l}-0.0206^{* *} \\
(0.007)\end{array}$ & $\begin{array}{l}- \\
-\end{array}$ & $\begin{array}{l}- \\
-\end{array}$ & $\begin{array}{l}- \\
-\end{array}$ & $\begin{array}{l}- \\
-\end{array}$ & $\begin{array}{l}- \\
-\end{array}$ \\
\hline Temperature & $\begin{array}{l}0.0013 * \\
(0.000)\end{array}$ & $\begin{array}{l}- \\
-\end{array}$ & $\begin{array}{l}- \\
-\end{array}$ & $\begin{array}{l}- \\
-\end{array}$ & $\begin{array}{l}- \\
-\end{array}$ & $\begin{array}{l}- \\
-\end{array}$ \\
\hline Temperature standard deviation & $\begin{array}{l}-0.0012 \\
(0.001)\end{array}$ & $\begin{array}{l}- \\
-\end{array}$ & $\begin{array}{l}- \\
-\end{array}$ & $\begin{array}{l}- \\
-\end{array}$ & $\begin{array}{l}- \\
-\end{array}$ & $\begin{array}{l}- \\
-\end{array}$ \\
\hline $\begin{array}{l}\text { Model } \\
\text { Dependent variable }\end{array}$ & $\begin{array}{l}(1) \\
\text { First stage }\end{array}$ & $\begin{array}{l}(2) \\
\text { Firm equity }\end{array}$ & (3) & (4) & $(5)$ & (6) \\
\hline \multicolumn{7}{|l|}{ Panel B: firm equity } \\
\hline County inequality in 2004 & $\begin{array}{l}- \\
-\end{array}$ & $\begin{array}{l}-0.0558 \\
(0.195)\end{array}$ & $\begin{array}{l}-0.362 \\
(0.651)\end{array}$ & $\begin{array}{l}2.865^{*} \\
(1.768)\end{array}$ & $\begin{array}{l}2.916^{*} \\
(1.753)\end{array}$ & $\begin{array}{l}2.346 \\
(1.605)\end{array}$ \\
\hline County population $_{\mathrm{t}-1}$ & $\begin{array}{l}-0.0029 \\
(0.001)\end{array}$ & $\begin{array}{l}-0.00189 \\
(0.007)\end{array}$ & $\begin{array}{l}0.0155^{* * * *} \\
(0.005)\end{array}$ & $\begin{array}{l}0.0103 \\
(0.008)\end{array}$ & $\begin{array}{l}0.0108 \\
(0.008)\end{array}$ & $\begin{array}{l}0.00579 \\
(0.008)\end{array}$ \\
\hline Rain & $\begin{array}{l}0.0119 * * \\
(0.006)\end{array}$ & - & $\begin{array}{l}- \\
-\end{array}$ & $\begin{array}{l}- \\
-\end{array}$ & - & $\begin{array}{l}- \\
-\end{array}$ \\
\hline Rain standard deviation & $\begin{array}{l}-0.0194 * * * \\
(0.007)\end{array}$ & - & $\begin{array}{l}- \\
-\end{array}$ & $\begin{array}{l}- \\
-\end{array}$ & - & $\begin{array}{l}- \\
-\end{array}$ \\
\hline Temperature & $\begin{array}{l}0.0013^{*} \\
(0.000)\end{array}$ & - & $\begin{array}{l}- \\
-\end{array}$ & $\begin{array}{l}- \\
-\end{array}$ & $\begin{array}{l}- \\
-\end{array}$ & $\begin{array}{l}- \\
-\end{array}$ \\
\hline Temperature standard deviation & $\begin{array}{l}-0.0018 \\
(0.001)\end{array}$ & $\begin{array}{l}- \\
-\end{array}$ & $\begin{array}{l}- \\
-\end{array}$ & $\begin{array}{l}- \\
-\end{array}$ & $\begin{array}{l}- \\
-\end{array}$ & $\begin{array}{l}- \\
-\end{array}$ \\
\hline County control variables & Yes & Yes & No & Yes & Yes & Yes \\
\hline Firm control variables & Yes & Yes & No & Yes & Yes & Yes \\
\hline State fixed effects & Yes & Yes & Yes & Yes & - & - \\
\hline Year fixed effects & Yes & Yes & Yes & Yes & - & - \\
\hline Two-digit industry fixed effects & Yes & Yes & No & Yes & No & No \\
\hline State*year fixed effects & No & No & No & No & Yes & Yes \\
\hline Industry*year fixed effects & No & No & No & No & Yes & Yes \\
\hline Number of observations Panel A & 3782 & 4470 & 4288 & 3782 & 3782 & 8320 \\
\hline Number of observations Panel B & 6381 & 7537 & 7497 & 6381 & 6381 & 9417 \\
\hline
\end{tabular}

Models (1) and (2) are estimated with a linear regression model (OLS) and take into account cross-sectional Kauffman Firm Survey weights. Models (3)-(6) are estimated with a 2SLS IV model for survey data. County inequality in 2004 is instrumented with average division rain fall and temperature between 1895 and 2003 and their corresponding standard deviations. Column (1) reports the first-stage regression. The definition of the variables can be found in Table 1. t-1 indicates a 1-year lag. The results in Panel A do not include the years 2004-2006 since the constraint variable is not available for these years. "Yes" indicates that the set of fixed effects is included. "No" indicates that the set of fixed effects is not included. "-" indicates that the indicated set of characteristics or fixed effects are comprised in the wider included set of fixed effects. Standard errors are clustered at the county level. Standard errors are given in parentheses. ***,** and * indicate significance at the $1 \%, 5 \%$ and $10 \%$ level respectively

*Significance at $10 \%$ level

**Significance at $5 \%$ level

***Significance at $1 \%$ level 
Table 4 The effect of county inequality on bank establishments per capita: pre- and post-2008

\begin{tabular}{|c|c|c|c|c|c|c|}
\hline Model & $\begin{array}{l}\text { (1) } \\
\text { OLS analysis }\end{array}$ & (2) & (3) & $\begin{array}{l}\text { (4) } \\
\text { 2SLS analysis }\end{array}$ & (5) & $(6)$ \\
\hline County inequality in 2004 & $\begin{array}{l}-1.215^{* * *} \\
(0.147)\end{array}$ & $\begin{array}{l}-0.734 * * * \\
(0.164)\end{array}$ & $\begin{array}{l}-0.718 * * * \\
(0.165)\end{array}$ & $\begin{array}{l}-4.814 * * * \\
(1.186)\end{array}$ & $\begin{array}{l}-5.737 * * * \\
(1.070)\end{array}$ & $\begin{array}{l}-5.857 * * * \\
(1.095)\end{array}$ \\
\hline Sub-prime crisis * county inequality 2004 & $\begin{array}{l}-0.170 * * * \\
(0.029)\end{array}$ & $\begin{array}{l}-0.145 * * * \\
(0.029)\end{array}$ & $\begin{array}{l}-0.193 * * * \\
(0.041)\end{array}$ & $\begin{array}{l}-0.118 * * * \\
(0.039)\end{array}$ & $\begin{array}{l}-0.081 * * \\
(0.038)\end{array}$ & $\begin{array}{l}0.292 \\
(0.286)\end{array}$ \\
\hline County population $\mathrm{t}_{\mathrm{t}-1}$ & $\begin{array}{l}-0.091 * * * \\
(0.005)\end{array}$ & $\begin{array}{l}0.048 * * \\
(0.019)\end{array}$ & $\begin{array}{l}-0.072 * * * \\
(0.006)\end{array}$ & $\begin{array}{l}-0.108 * * * \\
(0.008)\end{array}$ & $\begin{array}{l}0.039^{*} \\
(0.022)\end{array}$ & $\begin{array}{l}-0.100^{* * * *} \\
(0.010)\end{array}$ \\
\hline County wage inequality 2004 & & $\begin{array}{l}0.595 * * * \\
(0.182)\end{array}$ & $\begin{array}{l}0.593 * * * \\
(0.183)\end{array}$ & & $\begin{array}{l}-1.599 * * * \\
(0.545)\end{array}$ & $\begin{array}{l}-1.598 * * * \\
(0.549)\end{array}$ \\
\hline County Catholic-Protestant ratio & & $\begin{array}{l}0.002 \\
(0.015)\end{array}$ & $\begin{array}{l}0.002 \\
(0.015)\end{array}$ & & $\begin{array}{l}-0.017 \\
(0.021)\end{array}$ & $\begin{array}{l}-0.017 \\
(0.021)\end{array}$ \\
\hline County average age of the population & & $\begin{array}{l}0.438 * * * \\
(0.055)\end{array}$ & $\begin{array}{l}0.439 * * * \\
(0.056)\end{array}$ & & $\begin{array}{l}0.144 \\
(0.091)\end{array}$ & $\begin{array}{l}0.145 \\
(0.092)\end{array}$ \\
\hline State GDP per capita & & $\begin{array}{l}0.120 * * * \\
(0.019)\end{array}$ & & & $\begin{array}{l}0.139 * * * \\
(0.020)\end{array}$ & \\
\hline County land area & & $\begin{array}{l}0.021 * * \\
(0.010)\end{array}$ & $\begin{array}{l}0.021 * * \\
(0.010)\end{array}$ & & $\begin{array}{l}0.068 * * * \\
(0.017)\end{array}$ & $\begin{array}{l}0.068 * * * \\
(0.017)\end{array}$ \\
\hline State fixed effects & Yes & Yes & - & Yes & Yes & - \\
\hline Year fixed effects & Yes & Yes & - & Yes & Yes & - \\
\hline State $*$ year fixed effects & No & No & Yes & No & No & Yes \\
\hline Number of observations & 15,864 & 15,864 & 15,864 & 15,078 & 15,078 & 15,078 \\
\hline
\end{tabular}

Models (1)-(3) are estimated with a linear regression model (OLS). Models (4)-(6) are estimated with a 2SLS IV model. County inequality in 2004 is instrumented with average division rain fall and temperature between 1895 and 2003 and their corresponding standard deviations. The definition of the variables is found in Table 1. t-1 indicates a 1-year lag. "Yes" indicates that the set of fixed effects is included. Standard errors are clustered at the county level. Standard errors are given in parentheses

*Significance at $10 \%$ level

**Significance at $5 \%$ level

*** Significance at $1 \%$ level

of wealth inequality by looking at the local distribution of financial rents. We find that in more unequal counties, entrepreneurs are more likely to renounce to apply to a loan even if in need of finance because they fear to be turned down. Moreover, in more unequal counties, the proportion of owners' equity in startup financing is higher. We also find that in more unequal areas, the supply of bank capital, measured as bank establishments per capita, is especially negative after the 2007-2008 financial crisis.

Acknowledgments We would like to thank the Kauffman Foundation for providing access to its Firm Survey.

Funding During the writing of this paper, the Netherlands Organization for Scientific Research (NWO) generously supported Fabio Braggion through its VIDI Grant Program and Mintra Dwarkasing through its Mosaic Grant Program
Open Access This article is distributed under the terms of the Creative Commons Attribution 4.0 International License (http:// creativecommons.org/licenses/by/4.0/), which permits unrestricted use, distribution, and reproduction in any medium, provided you give appropriate credit to the original author(s) and the source, provide a link to the Creative Commons license, and indicate if changes were made.

\section{References}

Black, S. E., \& Strahan, P. E. (2002). Entrepreneurship and bank credit availability. Journal of Finance, 57(6), 2807-2834.

Braggion, F., Dwarkasing, M., \& Ongena, S. (2016). Household inequality, entrepreneurial dynamism and corporate financing. Tilburg: Tilburg University.

Calomiris, C. W., \& Haber, S. H. (2014). Fragile by design: the political origins of banking crises and scarce credit. Princeton NJ: Princeton University Press. 
Cetorelli, N., \& Strahan, P. E. (2006). Finance as a barrier to entry: bank competition and industry structure in local U.S. markets. Journal of Finance, 61(1), 867-892.

Comin, D., \& Nanda, R. (2014). Financial development and technology diffusion. Cambridge MA: Harvard Business School.

Engerman, S. L., \& Sokoloff, K. L. (1997). Factor endowments, institutions, and differential paths of growth among New World economies: a view from economic historians of the United States. In S. Haber (Ed.), How Latin America fell behind (pp. 260-304). Stanford CA: Stanford University Press.

Engerman, S. L., \& Sokoloff, K. L. (2002). Factor endowments, inequality, and paths of development among new world economies. Journal of LACEA Economia, 3(1), 41-109.

Fisman, R., \& Love, I. (2004). Financial development and intersectoral allocation: a new approach. Journal of Finance, 54, 2785-2805.

Glaeser, E., Scheinkman, J., \& Shleifer, A. (2003). The injustice of inequality. Journal of Monetary Economics, 50(1), 199-222.

Hoffman, P. T., Postel-Vinay, G., \& Rosenthal, J.-L. (2007). Surviving large losses: financial crises, the middle class, and the development of capital markets. Cambridge MA: Belknap Press of Harvard University Press.

Kerr, W. R., \& Nanda, R. (2009). Democratizing entry: banking deregulations, financing constraints, and entrepreneurship. Journal of Financial Economics, 94(1), 124-149.
King, R. G., \& Levine, R. (1993). Finance and growth: Schumpeter may be right. Quarterly Journal of Economics, 108, 713-737.

Levine, R., \& Zervos, S. (1998). Stock markets, banks and economic growth. American Economic Review, 88, 537-558.

Morck, R., Yavuz, M. D., \& Yeung, B. (2011). Banking system control, capital allocation, and economy performance. Journal of Financial Economics, 100(2), 264-283.

Rajan, R., \& Ramcharan, R. (2011). Land and credit: a study of the political economy of banking in the United States in the early 20th century. Journal of Finance, 66, 1895-1930.

Rajan, R. G. (2009). Rent preservation and the persistence of underdevelopment. American Economic Journal: Macroeconomics, 1(1), 178-218.

Rajan, R. G., \& Zingales, L. (1998). Financial dependence and growth. American Economic Review, 88, 559-586.

Robb, A. M., \& Robinson, D. T. (2014). The capital structure decisions of new firms. Review of Financial Studies, 27(1), $153-179$.

Sonin, K. (2003). Why the rich may favor poor protection of property rights. Journal of Comparative Economics, 31(4), 715-731.

Vollrath, D. (2013). Inequality and school funding in the rural United States, 1890. Explorations in Economic History, 50(2), 267-284. 